\title{
MANAJEMENT OF BORDERLAND AREA
}

\author{
Oleh \\ Dokman Marulitua Situmorang ${ }^{1}$ ), Oktavia Marpaung ${ }^{2}$ ) \& Albert Yansen ${ }^{3}$ ) \\ ${ }^{1}$ Institut Teknologi dan Bisnis Kristen Bukit Pengaharapan, Jawa Tengah \\ ${ }^{2}$ STIE Jayakarta, Jakarta \\ ${ }^{3}$ STIE Bhakti Pembangunan, Jakarta \\ Email: 11dokman@bukitpengharap.ac.id, ${ }^{2}$ oktavia_marpaung@stie.jayakarta.ac.id, \\ 3albert.yansen@gmail.com
}

\begin{abstract}
Trade activities that occurred at the border between Bengkayang Regency and Sarawak, specifically in Siding and Jagoi Babang districts, were in fact able to encourage domestic production. This study aims to see which management is in line with related fields in Bengkang Regency, the champion of Bengkayang Regency in Indonesia with Sarikin in Sarawak, Malaysia, which until now still uses traditional Cross-border Post or still uses the old-fashioned concept. The research method is Library Research and Field Research. As for the population in this study are the Customs and Excise staff of Jagoi Babang, the Border Society of Jagoi Babang, the TransBorder Post Guard Officer, the Jagoi Babang Entrepreneur. The border trade model is also run coordinated and integrated by BUMDes Together by synergizing the management of the potential for natural tourism, cultural tourism and culinary tourism and handicrafts (home industries) to be part of the goods offered.
\end{abstract}

Keywords: Manajement, Borderland Area, library Reseach, Field Research

\section{INTRODUCTION}

The national border development strategy is formulated to make the border region a gateway to neighboring countries through welfare, security and environment approaches in harmony. For this reason, centers of economic growth must be developed in directly adjacent districts. The social problems that exist in the border areas are as diverse as health, corruption, poverty, low nationalism, education and unemployment (Rissa. 2019). Bengkayang Regency is a regency located in the north of West Kalimantan Province. Administratively, the boundaries of Bengkayang Regency are as follows :

- North: Sarawak-East Malaysia

- - South: Pontianak Regency

- West: Natuna Sea and Singkawang City

- East: Sanggau Regency and Landak Regency

Table 1. Border Economic Growth in West Kalimantan Province (\%)

\begin{tabular}{|c|c|c|c|}
\hline District name & $\mathbf{2 0 1 6}$ & $\mathbf{2 0 1 7}$ & $\mathbf{2 0 1 8}$ \\
\hline Sambas & 5.24 & 5.13 & 5.10 \\
\hline Bengkayang & 5.15 & 5.66 & 5.37 \\
\hline Sanggau & 5.34 & 4.50 & 4.47 \\
\hline Sintang & 5.28 & 5.33 & 5.47 \\
\hline Kapuas Hulu & 5.28 & 5.39 & 5.23 \\
\hline
\end{tabular}

Source: West Kalimantan BPS, 2020

The facts mentioned above reveal that more needs to be done to optimize the potential utilization of border areas. Investment opportunities are wide open to increase the capacity of economic activities consumption, production and distribution/trade. The border region has great potential to become a center of growth because: (1) The border area is the entrance to foreign exchange flows into the country; (2) Rapid trade occurring at the border will encourage the growth of domestic production. Trade activities that occurred at the border between Bengkayang Regency and Sarawak, especially in Siding and Jagoi Babang 
districts, were found to be able to encourage the growth of domestic production. Agricultural products such as cocoa, rubber, small industries (home industries such as splints, handicraft woven chairs), medicines, clothing, food, beverages and accessories are traded to Kuching

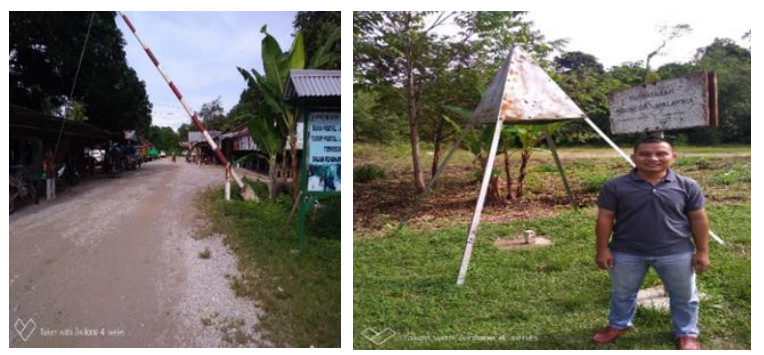

Image 1. Border conditions Jagoi babang

Through the Malindo Social Cooperation collaboration, it was agreed that the opening of the gates, Entikong-Tebedu, would be operated since February 25, 1991, which is the first official land/gate link in West Kalimantan. goods and people although on the other hand also cause vulnerability including Illegal trading activities are trading activities carried out without regard to the formal rules that apply include 2 types :

1. Small-scale illegal cross-border trade that does not heed cross-border crossing agreements or cross-border agreements.

2. Large-scale illegal trade that does not heed the rules of export - import trade.

After the abolition of the maximum spending limit of 600 ringgit (2012) turned out to have a positive impact on people living in the border area of Jagoi Babang District. The economic status of border communities has improved since the 'liberation' of trade. Houses are getting more and more good. Even the number of inns or inns began to increase, new traders also appeared there. The people who came to sell their products in jagoi babang were not only from the district of bengkayang but from pontianak, the landak district (Veneranda. 2019). It is estimated that Jagoi Babang Subdistrict will become a new city in West
Kalimantan Province and will grow rapidly due to the impact of neighboring and neighboring Sarawak, Malaysia.

Although there seems to be a glimpse of progress from trade activities taking place at the border, it is necessary to conduct a study of the border economy in Bengkayang Regency, as well as how studies can be carried out to provide optimal benefits for trade economic actors in particular and the community in Jagoi Babang District in general.

Some of the problems on the border area in Indonesia is the limitations of infrastructure and limitations of access into various sector, most important in matter of development of economy, education and health, The border areas in Indonesia is generally rural areas, where this area has slower development growth than elsewhere because appropriate isolated. The Indonesian government want to make the borderland as the porch future of the country, that is as the most important main gateway for the country. Border areas often got unbalanced treatment by the government such as economic development, infrastructure, and the facilities of health and education (Bima, 2018).

Border State border areas are regency/city areas that are geographically and demographically directly adjacent to neighboring countries and/or the high seas. The border area consists of land and sea border areas, which are widely spread with diverse typologies, ranging from the interior to the small front / outermost islands (Bappenas, 2010: 63). According to (Rahmaniah, 2011) border areas have their own uniqueness, in terms of geographical, social, and cultural aspects. So that the management of the border region requires a comprehensive policy, because it aims to create and increase economic and trade activities between the two countries and will have an impact on improving the welfare of the local community and increasing state income through export and import activities. 
Sholihah (2016) states, the border region has a strategic value in the success of national development and improvement of socio-economic welfare of the surrounding community. At present, it is assumed that people in the border region do not have optimal abilities because they are still shackled in poverty so that their level of welfare is low. The National Border Area according to Law Number 26 Year 2007 regarding Spatial Planning, is a strategic area that is seen from the point of view of defense and security interests. Border areas according to (Martinez, 1994) are categorized into four (4) types. First; aliniated borderland, in this category there is no crossborder activity as a result of the raging of wars, idealogical hatred conflicts, religious hostility, cultural differences and ethnic competition. Second; coexistent borderland, a border region where cross-border conflict can be suppressed to a level that can be controlled, although problems still arise in relation to the ownership of strategic resources in the border region. Third; interdependent borderland is a type of border region in which the two bordering areas show a picture of the stability of international relations between two or more bordering countries.

This study aims to see the extent of border management, especially in the field of trade that is in the way of the champion of the Babang Regency of Bengkayang, Indonesia with Sarikin in Sarawak, Malaysia, which until now still uses the traditional Cross-border Post or still uses the old-fashioned concept.

\section{RESEARCH METHODS}

In this writing the authors use empiricalsociological methods with techniques or methods or analytical approaches where problem-solving procedures by describing in detail and analyzing secondary data and primary data, things - things that are examined to get a complete picture or objects and subjects to be studied, things - This is done in the following way:

1. Form of Research a. Research library (library research) that is by studying various literatures, opinions of scholars, and legislation that are closely related to this research.

b. Field Research (Field Research) is conducting research plunging directly into the field with the intent of collecting data, information, information needed and having relevant to research problems.

2. Data collection techniques and tools

a. Direct communication technique is to make direct contact with data sources to obtain accurate data through interviews with crossborder postal guards, Immigration officers, and Customs and Excise who are considered to know and understand the problems to be examined.

b. Indirect communication techniques, namely data collection techniques carried out by means of indirect communication with data sources. This communication is carried out using a data collection tool in the form of a research questionnaire distributed to respondents (cross border post guards, immigration officers, and Customs and Excise ).

3. Population and sample.

a. The population is the whole object of research, while the population in this study are as follows: Babang

a. Customs and Excise officials Jagoi

b. The Jagoi Babang Border Society

c. Cross Border Guard Officers

d. Entrepreneur Jagoi Babang

b. Sample. The sample is part or representative of the population, sampling in this study using purposive sampling technique

\section{ANALYSIS AND DISCUSSION Jagoi Babang Subdistrict Overview (Border) Administrative Region}

Jagoi Babang Subdistrict is the widest subdistrict in Bengkayang Regency and is one of the 17 sub-districts in Bengkayang Regency which border directly with Sarawak (East Malaysia). Consists of 5 villages, namely Jagoi Village, Sekida Village, Sinar Baru Village, 
Semunying Jaya Village, Kumba Village, and Gresik Village. The width of Jagoi Babang District is $655 \mathrm{Km} 2$ or $12.14 \%$ of the area of Bengkayang Regency, and is about $115 \mathrm{Km}$ from the capital of Bengkayang Regency. Four of the 6 villages are included in the classification of underdeveloped villages, namely Sinar Baru Village, Gersik Village, Semuying Jaya Village, and Jagoi Sekida Village. Apart from Semunying Jaya Village, other villages in Jagoi Babang Subdistrict are directly adjacent to Sarawak (East Malaysia). The area of the village which has a direct boundary with Sarawak is $563 \mathrm{Km} 2$.

Table 2. Jagoi Babang District Administration Area

\begin{tabular}{|r|l|c|c|c|}
\hline No. & \multicolumn{1}{|c|}{ Village Name } & Number of & Area (KM $\left.{ }^{*}\right)$ & Persentase \\
\hline 1 & Desa Jagoi & 3 & 51,69 & 7,89 \\
\hline 2 & Desa Kumba & 2 & 65,52 & 10,00 \\
\hline 3 & Desa Sinar Baru & 2 & 250,00 & 38,17 \\
\hline 4 & Desa Gersik & 3 & 92,00 & 14,05 \\
\hline 5 & Desa Semuying Jaya & 2 & 75,00 & 11,45 \\
\hline 6 & Desa Jagoi Sekida & 3 & 120,79 & 18,44 \\
\hline \multicolumn{2}{|c|}{ Amount } & 15 & 655,00 & 100,00 \\
\hline
\end{tabular}

Source: Jagoi Babang in Numbers District, 2017

Relations between villages to Sarawak are generally easily accessible by local residents to interact with communities in the Sarawak region of Malaysia. This is because in the village / hamlet has long been established good relations (social ties) between villages in Sarawak that are connected by footpaths. Such conditions contribute to the flow of the economy from Indonesia - Malaysia through non-official doors, and the risk of leakage to the utilization of resources in the region.

Table 3. Name of Village and Subdistrict of Jagoi Babang Sub-District Which borders directly with Sarawak

\begin{tabular}{|c|c|c|c|}
\hline No. & Village Name & Border & Hamlet \\
\hline \multirow{3}{*}{1.} & \multirow{3}{*}{ Jagoi } & 1. Jagoi Babang & village \\
\hline & & 2. Risau & village \\
\hline & & 3. Take & - \\
\hline \multirow{3}{*}{2.} & \multirow{3}{*}{ Jagoi Sekida } & 1. Sejaro & village \\
\hline & & 2. Kindau & village \\
\hline & & 3. Belida & village \\
\hline \multirow{2}{*}{3.} & \multirow{2}{*}{ Kumba } & 1. Saparan & village \\
\hline & & 2. Sindang Kasih & - \\
\hline \multirow{2}{*}{4.} & \multirow{2}{*}{ Sinar Baru } & 1. Peleng & village \\
\hline & & 2. Sentimok & village \\
\hline \multirow{3}{*}{5.} & \multirow{3}{*}{ Gersik } & 1. Paum & - \\
\hline & & 2. Bantang Jaya & - \\
\hline & & 3. Senaning & - \\
\hline \multirow{2}{*}{6.} & \multirow{2}{*}{ Semunyin Jaya } & 1. Pareh & village \\
\hline & & 2. Semunyin & village \\
\hline
\end{tabular}

Source: Jagoi Babang in Numbers District, 2017

\section{Land Use}

Around $77.7 \%$ of the Jagoi Babang District area in 2013 was non-paddy land $(50,898 \mathrm{Ha})$, paddy fields amounted to $17.21 \%$ $(11,277 \mathrm{Ha})$ and only $5.09 \%(6,042 \mathrm{Ha})$ which was non-agricultural land. Land use in Jagoi Babang District is dominated for the plantation sector by $60.61 \%(40,354 \mathrm{Ha})$. The main commodity of plantation crops in Jagoi Babang District is oil palm. The area of oil palm plantations in Jagoi Babang District in 2013 was 14,972 hectares with a production of 2,252 tons. In addition to oil palm, a fairly prominent plantation commodity is rubber. The area of planting for this type of plant is 715 hectares with a production of 232 tons.

Table 4. Land Use in the Area Jagoi Babang District 2011 - 2013 (in Ha) 


\begin{tabular}{|r|l|r|r|r|}
\hline \multirow{2}{*}{ No.................................................. Land Use } & \multicolumn{3}{|c|}{ Years } \\
\cline { 2 - 5 } & \multicolumn{1}{|c|}{2011} & \multicolumn{2}{c|}{2012} & \multicolumn{1}{c|}{2013} \\
\hline 1 & Agricultural land & & & \\
\hline & Rice Fields & & & \\
\hline & Technical Irrigation & 0 & 0 & 0 \\
\hline & Half Technical Irrigation & 0 & 0 & 0 \\
\hline & Simple Irrigation & 0 & 0 & 0 \\
\hline & Village / Non-PU Irrigation & 426 & 482 & 435 \\
\hline & Rain-fed & 10.560 & 10.755 & 10.842 \\
\hline & Tides & 0 & 0 & 0 \\
\hline & Lebak & 0 & 0 & 0 \\
\hline & Other Polders and Rice Fields & 3.700 & 0 & 0 \\
\hline & land not rice fields & & & \\
\hline & 1. Tegal / Gardens & 4.638 & 3.331 & 3.588 \\
\hline & 2. Field / Huma & 602 & 552 & 744 \\
\hline & 3. Plantation & 56.700 & 40.121 & 40.354 \\
\hline & 4. Tree / Community Forest & 25 & 275 & 275 \\
& Planted & & & \\
\hline & 5. Pond & 0 & 0 & 0 \\
\hline & 6. Pool / Pool / Pool & 382 & 382 & 382 \\
\hline & 7. Grazing / Pasture & 2 & 2 & 4 \\
\hline & 8. Temporarily Not Tried & 2.000 & 2.485 & 1.810 \\
\hline & 9. Others & 1.073 & 1.073 & 3.741 \\
\hline 2. & Land Not Agriculture & & & \\
\hline & 1. 1. Houses / Buildings and & 721 & 1.011 & 1.011 \\
\hline & courtyards & & & \\
\hline & 2. 2. State Forests & 3.068 & 3.168 & 3.168 \\
\hline & 3. 3. Swamps (not planted) & 435 & 435 & 435 \\
\hline & 4. 4. Others & 1.168 & 1.428 & 1.428 \\
\hline & & & \\
\hline
\end{tabular}

Source: Jagoi Babang in Numbers District, 2017

\section{Population Conditions}

One important factor in regional planning is population problems, especially population numbers and distribution, as well as socioeconomic conditions which include levels of education, economic capacity, and health. The total population of Jagoi Babang District reaches 10,275 people consisting of 5,646 men and 4,629 women.

Table 5. Population Statistics According to Gender in District Jagoi Babang in 2017

\begin{tabular}{|c|c|c|c|c|}
\hline \multirow{2}{*}{ No } & \multirow{2}{*}{ Village } & \multicolumn{3}{|c|}{ Total Population (Soul) } \\
\cline { 3 - 5 } & & Male & Female & Total \\
\hline 1 & Jagoi & 1.331 & 1.233 & 2.564 \\
\hline 2 & Jagoi Sekida & 926 & 866 & 1.792 \\
\hline 3 & Kumba & 1.335 & 1.034 & 2.369 \\
\hline 4 & Sinar Baru & 811 & 590 & 1.401 \\
\hline 5 & Gersik & 581 & 507 & 1.088 \\
\hline 6 & Semunyin Jaya & 662 & 399 & 1.061 \\
\hline & Total & 5.646 & 4.629 & 10.275 \\
\hline
\end{tabular}

Source: Jagoi Babang in Numbers District, 2019

The largest population in the District of Jagoi Babang is in the Village of Jagoi, which is as many as 2,564 people. While the least population is in Semunyin Jaya Village, which is 1,061 people. The agriculture sector is still the main economic support in Jagoi Babang Subdistrict because the main source of income of the community in Jagoi Babang Subdistrict comes from the agricultural sector. However, this sector still needs to be optimized again so that its contribution to the economic structure in this district is getting better.

One important sector of capital in development is population because residents are both subjects and objects in development itself. Population as a subject means the existing population becomes the agent of development to be carried out. Population as an object means that the population is the goal of development itself, namely to build existing human beings.

Table 6. Area, Population, and Density in Jagoi Babang Sub-District by Village in 2017

\begin{tabular}{|c|l|c|c|c|}
\hline No & \multicolumn{1}{|c|}{ Village } & $\begin{array}{c}\text { Large } \\
\mathrm{KM}^{2}\end{array}$ & $\begin{array}{c}\text { Total } \\
\text { Population } \\
\text { (Soul) }\end{array}$ & $\begin{array}{c}\text { Density (Soul } \\
/ \mathrm{KM}^{2} \text { ) }\end{array}$ \\
\hline 1 & Jagoi & 51,69 & 2.564 & 50 \\
\hline 2 & Jagoi Sekida & 120,79 & 1.792 & 14 \\
\hline 3 & Kumba & 65,52 & 2.369 & 35 \\
\hline 4 & Sinar Baru & 250,00 & 1.401 & 5 \\
\hline 5 & Gersik & 92,00 & 1.088 & 11 \\
\hline 6 & Semunyin Jaya & 75,00 & 1.061 & 14 \\
\hline \multicolumn{2}{|c|}{ Total } & 655,00 & 10.275 & 16 \\
\hline
\end{tabular}

Source: Jagoi Babang in Numbers District, 2018 
The population of Jagoi Babang District is 10,275 people. If broken down by gender, the total male population is 5,646 and the total female population is 4,629. Population density in the District of Jagoi Babang is 16 people / KM2.

Viewed according to the village, the one with the highest population density is Jagoi village with a population density of 50 people / KM2 while the lowest population density is the new Sinar village with a population density of 6 people/KM2. Judging from the sex ratio, in general in the District of Jagoi Babang out of 100 women there are 122 men. From the sex ratio it can be concluded that in the District of Jagoi Babang in 2017 the male population is more than the female population.

Trading conditions

The trade sector is the most cultivated sector in Jagoi Babang District. Based on data from the Cooperative Office, UMKM, Bengkayang Regency Industry, the number of cooperatives both KUD / Non KUD in Jagoi Babang District is 10 (Ten) units where Jagoi Village has 5 (five) Cooperative units while the village that does not yet have Cooperative is Sinar Baru village and Grit Village. The most numerous trading sector is the type of retail traders, especially groceries trading. The existence of market facilities is very much needed because it considers the location of Jagoi Babang Sub-District right on the border crossing with Malaysia.
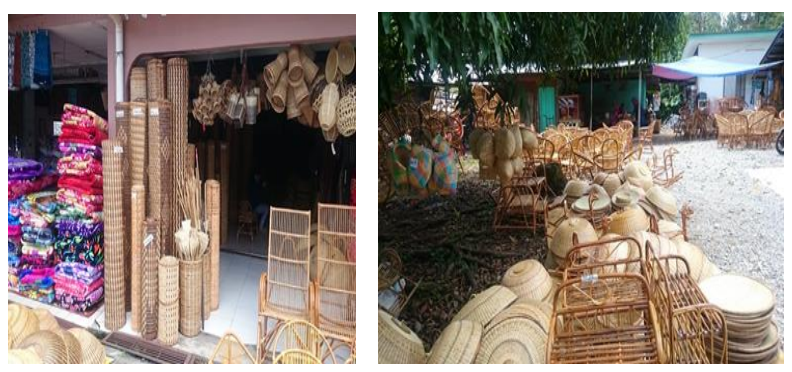

Image 2. Sarikin Market

At present the village market for Jagoi Babang sub-district is still not permanent. It is expected that in the future it can accelerate the economic improvement of the Jagoi Babang District. However, because the location of Jagoi Babang Subdistrict located in the border crossing area has a special characteristic with other regions, namely some people shop in the country of Malaysia (Serikin) on certain days, this causes economic activities that are not clearly visible in Jagoi District Gaping.

The following Table 4.21 shows many KUD and Non KUD in Jagoi Babang subdistrict by village.

Table 7. Number of KUD and Non KUD in Jagoi Babang District according to village

\begin{tabular}{|c|l|c|c|c|}
\hline No & \multicolumn{1}{|c|}{ Village } & KUD & $\begin{array}{c}\text { Non } \\
\text { KUD }\end{array}$ & Total \\
\hline 1 & Jagoi & 0 & 5 & 5 \\
\hline 2 & Kumba & 1 & 1 & 2 \\
\hline 3 & Sinar Baru & 0 & 0 & 0 \\
\hline 4 & Gersik & 0 & 0 & 0 \\
\hline 5 & $\begin{array}{l}\text { Semunyin } \\
\text { Jaya }\end{array}$ & 0 & 2 & 2 \\
\hline 6 & Jagoi Sekida & 0 & 0 & 0 \\
\hline \multicolumn{2}{|l|}{ Total } & $\mathbf{1}$ & $\mathbf{9}$ & $\mathbf{1 0}$ \\
\hline
\end{tabular}

Source: Jagoi Babang in Numbers District, 2017

The following is Figure 6 Border Trade Management with the determination of market location refers to the rules of the spatial boundary ( $4 \mathrm{~km}$ from the boundary line). If possible, stalled buildings (Figure 6) at the border, can be rehabilitated to become a border market. BUMDEs together in its management can work together (joint) of large entrepreneurs who are in the District of Babang / Jagago Regency Bengkayang. Cooperation is carried out biased in the form of organizational structure (shareholders) or in operations (as distributors).

Table 8. Staple Goods Supplies Circulating at Bengkayang and Origin of Goods

\begin{tabular}{|l|l|l|}
\hline No & Name of item & Origin \\
\hline 1 & Rice & Indonesia \\
\hline 2 & Sugar & Malaysia \\
\hline
\end{tabular}




\begin{tabular}{|c|c|c|}
\hline No & Name of item & Origin \\
\hline 3 & Bottle-Edible Oil & $\begin{array}{l}\text { Indonesia, } \\
\text { Malaysia }\end{array}$ \\
\hline 4 & Bulk Cooking Oil & Indonesia \\
\hline 5 & Boiler chicken meat & Malaysia \\
\hline 6 & Broiler chicken eggs & $\begin{array}{l}\text { Indonesia, } \\
\text { Malaysia }\end{array}$ \\
\hline 7 & $\begin{array}{l}\text { Sweetened condensed } \\
\text { milk }\end{array}$ & $\begin{array}{l}\text { Indonesia, } \\
\text { Malaysia }\end{array}$ \\
\hline 8 & Salt & $\begin{array}{l}\text { Indonesia, } \\
\text { Malaysia }\end{array}$ \\
\hline 9 & Wheat flour & $\begin{array}{l}\text { Indonesia, } \\
\text { Malaysia }\end{array}$ \\
\hline 10 & Instant noodles & $\begin{array}{l}\text { Indonesia, } \\
\text { Malaysia }\end{array}$ \\
\hline 11 & Cayenne pepper & Indonesia \\
\hline 12 & Shallot & Malaysia \\
\hline 13 & Garlic & Malaysia \\
\hline 14 & Anchovies & Indonesia \\
\hline 15 & Cabbage / Cabbage & Malaysia \\
\hline 16 & Potato & Malaysia \\
\hline 17 & Tomato & Indonesia \\
\hline 18 & Carrot-Beans & Malaysia \\
\hline
\end{tabular}

Development Agency, 2017

Based on observations and interviews in the field, staple goods cannot be entirely supplied from within the country. This is because the distribution of these goods to the border areas, especially Jagoi Babang, requires a considerable cost. Like for example sugar which comes entirely from Malaysia. The traders said that the sugar that comes from within the country (from the island of Java) is more expensive than the sugar that comes from Malaysia. Likewise with chicken and onion and white. Meanwhile, some types of vegetables such as carrots and beans are also supplied from Malaysia because they cannot be grown and produced from local agricultural land. In terms of supply, so far there have been no significant supply constraints.

Indonesian residents around the border have the right to shop for needs in Sarawak, Malaysia, amounting to 600 ringgit or around Rp 1,980 million. The profit is in Malaysia due to the exchange rate difference between the ringgit and the rupiah. Trade between Jagoi
Babang and Serikin-Sarawak (Malaysia) is enhanced by fiscal free facilities as enjoyed by residents of Batam Island, Riau Islands Province when they go to Singapore. This facility can encourage residents of Jagoi Babang Subdistrict to trade to SarawakMalaysia because they do not have to spend more fiscal. Fiscal by land is IDR 500,000.

Every weekend, Serikin Market is a special attraction for Indonesian traders, especially from West Kalimantan. The reason is that the Ringgit exchange rate is higher than the Rupiah, so traders can reap profits many times over. Every Friday afternoon the traders start coming. Saturday and Sunday they sell there. In terms of numbers, the activities in Serikin Market are very beneficial for the residents of Kampung Serikin because there are around 300 Indonesian traders here. The income of the Serikin residents from the Serikin market is mainly sourced from the rental of sales locations, room rentals as a place for lodging and storage of merchandise and visitors' parking spaces.

The average cost per person from Jagoi Babang to Serikin is 20 Malaysian Ringgit (RM), the same as the cost of ojek from Serikin to Jagoi Babang. Motorcycle taxi services are also for transportation of goods whose costs depend on the weight and size of the goods carried. Freight costs range from Rp. 60,000 to Rp. 100,000 (for the size of goods around $1.5 \mathrm{~m}$ $\mathrm{x} 1 \mathrm{~m}$ ) agreed through the bargaining process. The Jagoi ojeg people join the Jagoi Village Ojeg Association (PODJ). The services they offer only transport passengers and goods while unloading goods from vehicles (trucks for example) and putting them on motorbikes are the work of loading and unloading workers. 


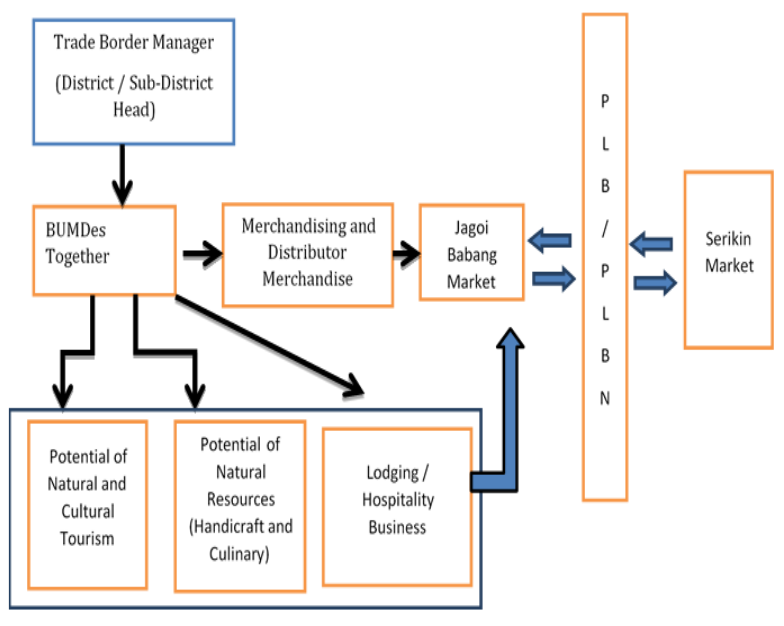

CONCLUSION

Based on the explanation and analysis in this study, the following conclusions can be drawn:

1. The process of economic and trade activities, (consumption, production and distribution) around the border has been going on for a long time. The needs of people who live around the border can be met with relatively cheaper prices. Specifically about land trade, up to now more still use motorcycle taxis.

2. Traders in the border area of Jagoi Babang - Serikin are not only local residents, but also from various regions in the provinces of West Kalimantan and outside West Kalimantan. Buyers of merchandise are not only from residents of Serikin, but also from other countries visiting Malaysia.

3. Types of goods that are circulating and traded at the border of Jagoi Babang - Serikin can be grouped into 3 categories, namely basic necessities, building materials and electronic and electrical materials.

4. In order to optimize the benefits of trading Jagoi Babang - Serikin, the choice to move traders to Jagoi Babang is a difficult choice to implement.

5. The Jagoi Babang-Serikut border management model must be coordinated and integrated (CIBM). The border trade model is also run in a coordinated and integrated manner by the BUMDes Together by synergizing the management of the potential for natural tourism, cultural tourism and culinary tourism and handicrafts (home industry) to be part of the traded goods.

\section{ACKNOWLEDGEMENT}

We appreciate the Bengkayang Regency Government, specifically the Bengkayang Regency Development Planning Agency Office

\section{REFERENCES}

[1] Ayustia. R., Usman. (2019). Empowerment Bidai Craft As A Solution On Eradicating Unumployment In The Borderland Area. Proceedings of the 5th International Conference of Project Management (ICPM) Yogyakarta.

[2]Badan Perencanaan Pembangunan Daerah Kabupaten Bengkayang. (2018). Studi Perdagangan Jagoi Babang.

[3]Badan Perencanaan Pembangunan Daerah Kabupaten Bengkayang. (2015). Studi Perbatasan Kabupaten Bengkayang.

[4]Koespramoedyo, Deddy. (2003). Kalimantan Development Border Area Strategy and Model. Directorate of Special \& Disadvantaged Areas Development Deputy for Regional Autonomy \& Regional Development BAPPENAS, Jakarta.

[5]Martinez, O. J. (1994). Border People. Tucson: University of Arizona Press.

[6]Hapsari1, R. V., Vuspitasari, K.B., Deffrinica. (2019). The Concept Of The Street Vendors' Management In The Border Area. Jurnal Terapan Manajemen dan Bisnis Vol. 5 No 1. Pp 19-26.

[7]Rahmaniah, E. (2011). Pembangunan perbatasan dan implikasinya terhadap keamanan masyarakat (community security) di perbatasan. Jakarta: Erlangga.

[8]Setya. N, B,. Prihanti P, L,. Suprihanto, S., (2018). Krayan Heart of Borneo: Indonesian Potential Tourism Destination Enjoyed by 
Malaysia. in The 1st International Conference on South East Asia Studies, 2016, KnE Social Sciences, pages 118-129.

[9]Sholihah, I. (2016). Kebijakan Hukum Pembangunan Kawasan Perbatasan Melalui Infrastruktur Berbasis Teknologi. Rechts Vinding., 5(3): 305-321. 